\title{
RIFTON FINNS: AN ETHNIC ENCLAVE IN ULSTER COUNTY, NEW YORK
}

\author{
Mika Roinila, \\ Bethel College
}

\section{INTRODUCTION}

When you begin to consider the Finns of New York State, there are two obvious foci that have received the majority of attention in the ethnic literature. The presence of some estimated 20,000 Finns in New York City during the 1920s provided a large population with its myriad cultural, religious and social organizations and activities. The heyday of the large Finnish population has passed, and as of 2000, a total of 3,466 Finns lived in New York City. ${ }^{1}$ This number remains the highest population within the state. Due to this large population size, much has been written about their existence, for example, in Brooklyn and Manhattan. ${ }^{2}$ A second significant concentration of Finns within the state has always been the Finger Lakes region in western New York State. Here, in cities and towns such as Van Etten, Spencer, Millport, and Ithaca, activities and organizations have existed for decades and have also received academic interest. ${ }^{3}$

However, there is one location that has not received attention since the publication of the 1926 History of Finnish-Americans by Salomon IImonen. ${ }^{4}$ In this publication, the town of Rifton or Ulster Park in the county of Ulster is listed with the names of some 13 Finnish individuals. There is nothing rare in this list of names, as Ilmonen also lists the names of Finnish immigrants in numerous other locations throughout the state and across the country. What is significant, however, is the fact that some seventy years later, the concentration of Finns in Rifton ranks seventh in the entire state of New York. Neighboring High Falls, only some eight miles west of Rifton, has the fifth highest concentration of Finns in the state (Tables $1 \& 2$, Map 1). While the absolute number of Finns in these two villages is very low, their proportion within the entire village population is more significant. And as it turns out, the historical presence of the Finns in this part of New York was even more significant in the past compared to the present. 
My interest in this Finnish concentration began as a result of my relocation to the region in 2000. As I have lived in nearby Tillson, NY and my children have attended elementary school in Rifton, we discovered the existence of streets with Finnish names. Suominen's Road and Tervo Drive have obvious Finnish connections. As my daughters participated in the local Brownies program, I came across a plaque at the Rifton Volunteer Fire Station which honored former firefighters of the village. On this plaque, the names of several Finns were listed. Who were these Finns? Where did they come from? Where did they live? Where are their descendents? These were some of the questions I began to ponder as I discovered that Finns had once lived in this small village.

\section{METHODOLOGY}

As mentioned earlier, virtually nothing has been written about the Rifton Finns since 1926. With the names provided by Ilmonen in his text, I scoured the local telephone directories. I sent letters to possible Finns in the region, with limited success. Some

TABLE 1. TOP 10 PLACES ACCORDING TO ABSOLUTE NUMBER, 2000

\begin{tabular}{|l|c|c|c|}
\hline Place & Total Pop & \# of Finns & \% Finns \\
\hline New York city & $8,008,278$ & 3,466 & 0.04 \\
\hline Yonkers city & 196,086 & 139 & 0.07 \\
\hline Ithaca city & 29,006 & 136 & 0.47 \\
\hline West Islip CDP* & 29,105 & 131 & 0.45 \\
\hline Irondequoit CDP & 52,346 & 119 & 0.23 \\
\hline Albany city & 95,658 & 117 & 0.12 \\
\hline Buffalo city & 292,648 & 111 & 0.04 \\
\hline Syracuse city & 147,326 & 106 & 0.07 \\
\hline Coram CDP & 34,979 & 94 & 0.27 \\
\hline South Hill CDP & 6,099 & 93 & 1.52 \\
\hline
\end{tabular}

CDP - Census Designated Place, defined as a statistical entity that serves as a statistical counterpart of an incorporated place for the purpose of presenting census data for a concentration of population, housing, and commercial structures that is identifiable by name, but is not within an incorporated place.

Source: US Census Bureau - Census 2000, American Factfinder http://factfinder.census.gov 
TABLE 2. TOP 10 PLACES ACCORDING TO PERCENTAGE CONCENTRATION in 2000

\begin{tabular}{|l|c|c|c|}
\hline Place & Total Pop & \# of Finns & \% Finns \\
\hline Van Etten village & 572 & 44 & 7.69 \\
\hline Spencer village & 733 & 39 & 5.32 \\
\hline Millport village & 297 & 7 & 2.36 \\
Bemus Point village & 342 & 8 & 2.34 \\
High Falls CDP & $\mathbf{6 0 5}$ & $\mathbf{1 2}$ & $\mathbf{1 . 9 8}$ \\
\hline East Ithaca CDP & 2,292 & 42 & 1.83 \\
\hline Rifton CDP & $\mathbf{4 6 5}$ & $\mathbf{8}$ & $\mathbf{1 . 7 2}$ \\
\hline Forest Home CDP & 1,018 & 17 & 1.67 \\
South Hill CDP & 6,099 & 93 & 1.52 \\
\hline Shinnecock Hills CDP & 1,798 & 27 & 1.50 \\
\hline Source: US Census Bureau & - Census 2000, American & Factfinder - \\
\hline
\end{tabular}

Source: US Census
http://factfinder.census.gov

responded positively and were excited to help. I also contacted the local town halls of Esopus and Rosendale to examine property maps to determine where the Finns may have lived. I also was able to gather historical census information and additional family names from the 1920 and 1930 US Censuses available online at Ancestry.com. Additional material was located from historical censuses available at the University of Virginia Library and through Ellis Island Passenger Arrival Records. ${ }^{5}$ Local newspaper coverage of several major events that included the Rifton Finns were found in the Kingston Daily Freeman as well as the Finnish-American newspaper New Yorkin Uutiset. Several interviews with local and not-so-local Finns and their descendants took place between 2003-2005 to provide more detail to the material being collected, and finally, photographic evidence of the Finns in the region were obtained. These include photos of individuals and families, houses and structures, as well as events and activities.

\section{HISTORY \& DEVELOPMENT}

Rifton, NY is located along the Wallkill River, which flows northward and joins the Roundout Creek before draining into the Hudson River at Kingston. The town of Rifton is situated some 95 miles north of New York City, and has an old history. It was first settled in 1709 by the Dutch who arrived in the New World. This is the birthplace and childhood home of the reknown Sojourner Truth (1797-1883), who was a former slave, abolitionist, preacher and advocate of women's rights. Rifton was well known for a carpet mill that was built in 1889 and employed some 200 men, women and children. Situated along the banks of the Wallkill, the mill burned down in 1923. Rifton is also known for the construction of Sturgeon Pool Dam which was completed in 1923 and provides a large reservoir of water that caused the town of Saltpetreville to be drowned. Saltpetreville, in turn, was well remembered as a major manufacturer of gunpowder during the US Civil War for the Union forces. ${ }^{6}$

It has been impossible to determine when the first Finns arrived in the region. IImonen does not mention this in his book, and census information is limited. It is 
known, however, that there were no Finns in the region in 1910. By 1920, however, there was a total of 42 Finns living in 7 homes. In 1930, a total of 95 Finns lived in 19 homes. And while nearby High Falls had a higher concentration of Finns in the year 2000 , it should be mentioned that in 1930 , Rifton was home to $82 \%$ of all the Finns who resided in the entire Ulster County. Thus Rifton is most important in this study (Table 3 ).

TABLE 3. FINNISH CONCENTRATION IN ESOPUS \& RIFTON, NY 1920-1930 \& 2000

\begin{tabular}{|l|c|c|c|c|}
\hline Census Year & $\begin{array}{c}\text { Known Finnish } \\
\text { population } \\
\text { in Rifton }\end{array}$ & $\begin{array}{c}\text { Total } \\
\text { population of } \\
\text { Esopus }\end{array}$ & $\begin{array}{c}\text { Total } \\
\text { population of } \\
\text { Rifton }\end{array}$ & \% Finns \\
\hline 1920 & 42 & $3,913^{1}$ & $\sim 186$ & $\sim 22.58 \%$ \\
\hline 1930 & 95 & $4,167^{1}$ & $\sim 198$ & $\sim 47.97 \%$ \\
\hline 2000 & 8 & 9,331 & $465^{2}$ & $1.72 \%$ \\
\hline
\end{tabular}

Source: 1920 and 1930 US Census data obtained via correspondence with US Census Bureau Library, Washington DC October 28, 2005. 2000 Census Data from American Factfinder - http://factfinder.census.gov

${ }^{1}$ Until the 1980s, Rifton was part of the Town of Esopus, and thus statistics separating the population of Esopus and Rifton are not available.

${ }^{2}$ In 2000, Rifton was recognized as a Census Designated Place (CDP), and thus is identified with a distinct population apart from the former association with the Town of Esopus.

It is unfortunate that no past population data is available for the village of Rifton independent of the Town of Esopus. Contact with the US Census Bureau Library in Washington DC indicates that it is impossible to know the population of Rifton alone. Contact with local Esopus Town Historian Florence Prehn also verifies this fact. ${ }^{7}$ However, some estimates can be made. The total population of Esopus in 2000 was 9,331 individuals. With Rifton added to this figure, the total population of the region formerly known as Esopus was 9,796 individuals. The population of Rifton represented a $4.75 \%$ share of the total population of the formerly designated settlement of Esopus. If this percentage share is used to estimate and establish the population of Rifton for 1920 and 1930, and in turn the concentration of Finns in the village, we notice that the concentration of Finns is highly significant. The proportion of Finns in Rifton for 1920 may have been as high as $23 \%$ and in 1930 it may have been nearly $50 \%$ of the village population. This concentration may well have been likely, and much of the following information, such as school enrollments, supports this concentration.

The earliest arrival to the US involved the immigration of a 50-year old Mary Eversti (also mentioned by name by llmonen), who had immigrated to the US in 1880, and was a border in the home of lisac Suomela. ${ }^{8}$ The source region for the majority of these migrants appears to have been the New York City area. Interviewees moved to the area from Brooklyn and Jersey City. ${ }^{9}$ The roots in Finland range from Karelia in the east to Oulainen in the west. $^{10}$

According to town property maps, most of the Finns located themselves several miles away from the town center. Finns found property for sale along Hardenburg Road 
and Old Post Road. Some built their homes along Church Hill Road (Map 2). In the 1920s, Rifton was considered a

"one horse town. It consisted of a grocery store, a gas station, a family run hotel for a few summer residents and a bar. There also was a volunteer fire department and bus stop for Kingston and New Paltz. Our farm was two miles from the village, so we either had to 'hoof it' or take the horse and buggy, as no one in the family had an automobile" ${ }^{11}$

Family size was usually quite large. According to the 1930 Census, the Suominen and Hernesaho families, for example, had ten children in each family. The Salmi family had nine family members. The Hilden family had 7 members, and the Rimmi family had six members. There were also some single men and families with only a few children. In all the families, the 1920 and 1930 censuses also indicates that all of the children had been born in the United States, whereas all the parents were born in Finland. It was also common for a few of the Finnish families to host boarders from New York city, mostly boys, who were sent by their parents to "enjoy the good clean atmosphere of country living. Sometimes the parents would stay for awhile themselves". ${ }^{12}$ In 1930, a total of eight boarders, all under the age of ten, lived with Alexandra Kesti who managed such a boarding home. ${ }^{13}$

Hilma (Suominen) LaLima of Kingston (b.1918) recalls the Old Stone School of Rifton, where at least half of the students were Finns. The Suominen family, with 10 children, made up a large part of the student population! On one occasion, Hilma was made to stand in the corner of the school by a pot stove for speaking in Finnish. The children did not know English until they began school. From the 1920s, Hilma recalls her father Jalmar taking the kids to school during the winter with a horse and buggy when the weather was bad. The distance of 3 miles from the Suominen homestead to the school was usually by foot. ${ }^{14}$ Finnish children and several parents also got involved in extracurricular activities, such as the 4-H Club which was led by Finnish Doris Wiren in $1930 .^{15}$ The strong presence of Finnish children in school reflects the total population of Rifton during these years, and provides support for the estimated statistics noted earlier in this paper.

According to the correspondence and interviewees with several current and former Rifton area Finns, carpentry was the main occupation in the area. ${ }^{16}$ The 1920 and 1930 Census information verifies this as well. In 1920, of a total of seven families in the region representing 42 individuals, a total of seven individuals were carpenters. Thus, $64 \%$ of the eleven Finns able to work in 1920 were involved in carpentry. Among the heads of household, four were carpenters followed by three sons. There were also two laborers, one builder and one horse farmer. For the carpenters, house construction was their main industry, but there were also three carpenters, a builder and a laborer who worked on a shipyard and dock. ${ }^{17}$ At least one Finn also worked on the Dashville Dam construction (completed in 1920), which is tied to the Sturgeon Pool construction that was finished in $1923 .{ }^{18}$ In 1930, a total of 15 carpenters were found from the working population of 25 . Thus, $60 \%$ of the Finns able to work in 1930 were involved in this trade. Other occupations in 1930 involved a store manager, two farm managers, equipment man, mechanic, farm helper, nurse, servant, laborer and a stenographer (1930 US Census, Esopus, Ulster Co.NY). In the 1940s, some found construction 
employment on the Lackawana Tunnels, which were to carry water from large reservoirs to the residents of New York City. ${ }^{19}$

Activities among the Rifton Finns included sauna nights, sewing bees, support for the Finnish war efforts during WWII, as well as church events. One of the identifying features of the Finn is the sauna. Local non-Finnish residents have mentioned to me that they recall the sauna smoke rising into the air every weekend throughout Rifton! Indeed, many of the Finns visited the homes of countrymen who did have a sauna. According to Linda Ritner,

"we grew up going to the Saturday night sauna's at Kestie's house and we have used every sauna in Rifton at one time or another. I know where they are and can remember them vividly." 20

Today, the saunas are falling apart and are no longer in use, but they are still visible in the woods and backyards of the former Finnish homes. And if the sauna is not a separate building, it has been built into the basement, such as the very thick concrete walled basement sauna of Raymond Tresvik, who moved to Rifton after $1927 .^{21}$

Sewing bees were also organized by the Finnish women, and during the 1940s, the local Finns sent their support to the Finnish Winter War effort. According to newspaper accounts, "this Rifton group has knitted many pairs of mittens for the Finnish soldiers and have laid plans for much effective work to be done in the future". According to the paper, the "Rifton Finnish Colony" at the time had a total of 22 families, and a total of 35 individuals who were participating in this effort. ${ }^{22}$ During the 1940 s, Finns also got involved in the war itself in large numbers. According to the History of Rifton, a total of 22 Finnish surnames out of a total of 83 individuals are listed in the Rifton Honor Roll with names of those who served their country in WWII. This represents $26 \%$ of all Rifton residents! $!^{23}$ An example of this service was Victor Tresvik, who joined the US Air Force and flew missions over Germany in WWII, where he shot down four enemy planes. $^{24}$

Some interviewees also indicated the occurrence of occasional church services that were held locally at the Rifton Methodist Church on Church Hill Road, as visiting ministers would provide communion services and even confirmation classes. The Kingston Evangelical Lutheran Church was also used for confirmation ceremonies. ${ }^{25}$ However, the number of church going Finns appears to have been quite small. There is also some indication that a small group of Finns supported the Apostolic Lutherans, and met at the homes of some of the local Finns. Once a year, a visiting pastor from Michigan arrived to perform a special meeting. ${ }^{26}$ There was also an attempt by some Finns to open a co-operative store on the Main Street of Rifton, but after a brief period, this did not succeed. The building that allegedly was the site of the co-op, is today the site of the Rifton Post Office. ${ }^{27}$

One of the best known locations within the entire Rifton/High Falls region is Williams Lake. This is the site of a well known resort lodge established by a Finn named Gustaf Williams in 1929. Maintained and owned to this date by grand-daughter Anita Williams-Peck, the resort has attracted many Finns from New York City, including members of the Finlandia Foundation who attend a midsummer picnic at this location 
every year. Support for he resort among the Finns is still evident, although not as much as in the past.

[The lodge] "catered to everybody. Mostly the singles crowd. Many more Finns came here then [in the past], because of my grandfather I think, and then my father. But as the years go on, even locally, nobody thinks of us as being anything but American. When I tell people that I am Finnish, they say "really", you know. Unless they know my grandfather, and some of the old-timers do... my grandmother and grandfather definitely had accents. They weren't American and came from another country." ${ }^{28}$

While the Williams Lake Resort is known by many of the Rifton Finns, it appears that only a few of them ever visited the resort, which also means that they know little about the origins of this important landmark. Similarly, according to Anita Williams-Peck, she is not aware of the Finnish enclave in Rifton, and never heard about it in conversations with her father or grandfather. ${ }^{29}$ There appears to be an apparent lack of knowledge about the lodge among the local Finns in this area, which has been explained by some as a result of the division of class among the Finns. The well-to-do Finns, such as the proprietor of Williams Lake Resort and other New York City Finns who visited his resort did not associate with the lower working class Finns who lived in the Rifton area. ${ }^{30}$ Today, while no Rifton area Finn visits the resort, Williams Lake Resort still attracts Finnish-Americans from New York City to attend a mid-summer picnic sponsored by the Finlandia Foundation. ${ }^{31}$

By the 1950s, Finnish activities had declined, but some new Finns arrived in the region and some activities were still maintained. This includes Kerttu Barnett (b.1924 in Sortavala), who moved to the United States in 1957 and arrived in Rifton in 1960, and was amazed that she had accidentally moved into a Finnish community. In her own words, the realization of Finnish neighbors is noted below:

"My family, my two children and my husband moved from New York to the countryside and we rented this house, and the next morning I went outside - it was summertime - and there was along this hill up the road a big farmhouse and somebody was yelling there 'Mother, where is my horse?' - 'Äiti, missä on hevonen?' I thought that I was hallucinating. How could I hear Finnish right like that? They were real, true Finns and that's how we were introduced into this community of Finn. And then we started...I and some others, we started to have a coffee party every month in each house, and everyone bought something to eat."32

Some 20-30 people would attend the coffee parties during the late 1950s and 1960s, but little by little the events declined and disappeared. Aside from the coffee parties, people attended saunas as well, but with age the older generation stopped having these events and the younger generation did not carry on with these traditions. ${ }^{33}$ The younger generation has also left the region. While there are still a few who have remained, a large number have moved away. Some of the destinations are nearby, but some include destinations as far as Vermont, Minnesota, Arizona, California, and Washington state. ${ }^{34}$ 


\section{CONCLUSIONS}

To discover a Finnish ethnic enclave in Rifton was a surprise to the author. To find the whereabaouts and the history of these people in the region has been an intriguing investigative process which has helped me gain a better understanding of the impact the Finns made in this region of New York. The evidence of their existence is easy to find, once you look for it and know where to look. Many of the Rifton Finns have found their final resting place in the nearby Rosendale Cemetery. Several of the old Finns have their graves here, which can easily be identified as you walk along the many rows of tombstones. The dilapidated homes and saunas of the Finns are also evidenced in the landscape. Although there are still a few original settlers and their descendents who have remained and still live in their original homes, the sauna smoke that rose into the air in the past and made the Finnish presence known to the non-Finns is no more. The enclave that developed in the 1920s is still here, and it has been a pleasure to share their story with the readers.

\section{ACKNOWLEDGEMENTS}

Much credit is due to the many people who helped in providing valuable information to this project. Special thanks go to the late Eva (Suomela) Mertz of Port Charlotte, FL whose unpublished manuscript, paper clippings, and keen sense of memory were greatly appreciated. Thanks to two anonymous reviewers of this manuscript, and to all the families and individuals I was able to reach with this project. Without your interest, this work would not have been possible.

\section{ENDNOTES}

1 US Bureau of the Census, American Factfinder, Census 2000 located at http://factfinder.census.gov/ (accessed March 30, 2006).

${ }^{2}$ Some literature dealing with the Finns of New York State include Ewert Blomberg, Brooklynin Suomalaisen Ewavnkelis-Luteerilaisen Seurakunnan Historia. Hancock, Michigan, 1904; A.Loeb, "Finnish Life in New York", in New York Magazine, Feb.4, 1940, New York, 1940; Wilho Hedman, "Katsaus Suur-New Yorkin Suomalaisten Historiaan", in Siirtokansan Kalenteri 1944, Duluth, 1943, pp.81-88; Frank Blomfelt, "August Willandt: En Emigrantmissionär i New York", in Sanct Olof, Marienhamn, 1964, pp.67-73; and Esko Tommola, Uuden Maan Rakentajat:New Yorkin Suomalaisten Tarina. Otava, Helsinki, 1989.

${ }^{3}$ Two works on the Finger Lakes Finns include William Hoglund, "Finnish immigrant farmers in New York 1910-1960", in O.Fritiof Ander (ed.), In the Trek of the Immigrants, Rock Island, 1964, pp.141-155; and Melissa Ladenheim, The Sauna in Central New York. New York, 1986.

4 The works of Reverend Salomon IImonen are very significant in early FinnishAmerican history. Ilmonen published several works which examine the Finnish settlements across the country, and he mentions Rifton in Amerikan Suomalaisten Historia III: Yhdysvalloissa ja Canadassa Olevat Suomalaiset Asutukset, Hancock, Michigan, 1926, $344 \mathrm{p}$. 
${ }^{5}$ University of Virginia library located at

http://fisher.lib.virginia.edu/collections/stats/histcensus/ - accessed December 18, 2004 and The Ellis Island website at http://www.ellisisland.org/ - accessed December 18, 2004.

${ }^{6}$ Map of the Rifton Valley, a Rifton Land Corporation map (no publication date) obtained in Fall 2002 from Boy Scout Troop \#17, Tillson, NY 12486.

${ }^{7}$ Florence Prehn. Conversation Oct.19, 2005 in Rifton, NY.

${ }^{8}$ Data obtained from the 1920 US Census, Esopus, Ulster Co.NY accessed through Ancestry.com (December 19, 2004)

9 Interviews included local residents Hilma LaLima (Suominen), June 21,2004, in Kingston, NY; Raymond Tresvik, June 29, 2004 in Rifton, NY, and an anonymous interviewee May 21,2004 in Rifton, NY.

${ }^{10}$ Noted in Salomon Imonen, 1926.

${ }^{11}$ Much information was received from Eva Mertz (Suomela) of Port Charlotte, FL who was interviewed July 18, 2004 in Tillson, NY.

12 Mertz, Eva Mertz (Suomela). And One Was Missing \& Retirement Can Be Fun, Unpublished manuscript, October 2003, p.9.

${ }^{13}$ US Census, 1930, accessed through Ancestry.com (December 19, 2004)

${ }^{14}$ Interview with Hilma LaLima (Suominen), June 21,2004, in Kingston, NY.

${ }^{15}$ Anna Devine, History of Rifton. n.p., n.d.

${ }^{16}$ Correspondence with Albert Aho, July 26, 2004, Big Lake, Minnesota.2004; interview with Kerttu Barnett, November 14, 2004 in Ulster Park, NY; interview with Hilma LaLima (Suominen), June 21,2004, in Kingston, NY 2004; interview with Eva Mertz (Suomela), July 18, 2004 in Tillson, NY; correspondence with Linda Ritner, June 26, 2004, South Burlington, VT.; and interview with Raymond Tresvik, June 29, 2004 in Rifton, NY.

171920 US Census, Esopus, Ulster Co.NY., accessed through Ancestry.com (December 19, 2004)

${ }^{18}$ Interview with Hilma LaLima (Suominen), June 21, 2004, in Kingston, NY.

${ }^{19}$ Ibid.

${ }^{20}$ Correspondence with Linda Ritner, June 26, 2004, South Burlington, VT.

${ }^{21}$ Interview with Raymond Tresvik, June 29, 2004 in Rifton, NY. 
22 Kingston Daily Freeman, "Finnish-Americans at Rifton Lend Hands to Cause", Jan.27,1940, Kingston, NY.

${ }^{23}$ Anna Devine, History of Rifton. n.p., n.d.

${ }^{24}$ Interview with Raymond Tresvik, June 29, 2004 in Rifton, NY

25 Ibid.

${ }^{26}$ Anonymous interviewee May 21,2004 in Rifton, NY.

27 Ibid.

${ }^{28}$ Interview with Anita Williams-Peck, Nov.8, 2004, in Rosendale, NY.

29 Ibid.

${ }^{30}$ Conversation with Dr.Richard Impola and Helvi Impola, February 12, 2006 in New Paltz, NY.

31 The Finlandia Foundation is the most important private source of support for Finnish culture in the United States. The New York City Chapter was organized in 1960, and with numerous chapters across the country, it actively supports, preserves and promotes Finnish culture. The New York Chapter has visited Williams Lake regularly for many years and has mentioned it on their website. For more information, see http://www.finlandiafoundation.org/ (accessed March 27, 2006).

${ }^{32}$ Interview with Kerttu Barnett, November 14, 2004 in Ulster Park, NY.

${ }^{33}$ Interview with Paula Bojansky, November14, 2004, in Ulster Park, NY.

34 Correspondence with Albert Aho, July 26, 2004, Big Lake, Minnesota.2004; Correspondence with Eva Mertz (Suomela), August18, 2004. Port Charlotte, FL; and correspondence with Linda Ritner, June 26, 2004, South Burlington, VT 